International Journal of Linguistics, Literature and Culture
Available online at https://sloap.org/journals/index.php/ijllc/
Vol. 7, No. 4, July 2021, pages: 194-200
ISSN: 2455-8028
https://doi.org/10.21744/ijllc.v7n4.1649

\title{
Cognitive Principle of Foregrounding in the Mass-Media
}

Khilola Otakhonova ${ }^{a}$

Article history:

Submitted: 27 March 2021

Revised: 18 April 2021

Accepted: 7 May 2021

\section{Keywords:}

cognitive principles

commentators;

internet journalism;

media communications;

print media;

publishing houses;

republican conference;

strong civil society;

\section{Corresponding author:}

Otakhonova, K.

Uzbekistan State University of World Languages

Tashkent, Uzbekistan.

Email address: ozodbekjon-nematovich@mail.ru
International journal of linguistics, literature and culture (C) 2021. This is an open access article under the CC BY-NC-ND license (https://creativecommons.org/licenses/by-nc-nd/4.0/).

\footnotetext{
${ }^{\text {a }}$ Uzbekistan State University of World Languages, Tashkent, Uzbekistan
} 


\section{Introduction}

The media has always been a mirror of the development of society, one of the main tools in shaping the consciousness, worldview and political level of the people. The past has been a period of multifaceted development for the media, as well as for all sectors. From the first years of independence, our country has been carrying out large-scale reforms to build a democratic state governed by the rule of law and a strong civil society. In particular, ensuring freedom of information and speech, liberalization of this area has been identified as an important priority in building a democratic, legal state and a strong civil society in Uzbekistan (Otten, 1992). In 1991, there were 395 media outlets in Uzbekistan, but today their number has reached 1,437. Currently, the existing non-state print media accounts for $62.7 \%$ of the total print media. In 1990, there were 9 publishing houses, today their total number is 112 . In 2015, "Development of Internet journalism in Uzbekistan It was worthwhile to hold a republican conference on "Current issues". As a result, the foundation has consistently worked to train highly qualified journalists, analysts and commentators, establish effective creative contacts with reputable international media companies and foreign colleagues, and improve the professional skills and experience of young professionals" (López-Guimerà et al., 2010). Given the diversity of views in the media, taking into account the events taking place in our country and abroad, the task is to ensure more openness and transparency of the reforms carried out by our people, more active coverage of foreign and domestic policy in Uzbekistan. All conditions for this have been created in our country.

\section{Materials and Methods}

The Uzbek media, which has such a wide range of opportunities and is one of the most important institutions of civil society, is on the path to further democratization of all spheres of life, which today reflects the public opinion to be a driving force. Today, the legislation aimed at establishing various benefits for the media is being improved. In particular, the decision of December 30, 2011 "On additional tax incentives and benefits for the further development of the media" is a clear proof of this. The decision strengthens the economic base of the media by expanding the capacity of the media to ensure the rights and freedoms of citizens in the field of information. Because economically free, strong and independent media have the ability to provide analytical, prompt and objective information to the public The Constitution of the Republic of Uzbekistan is the main source of the legal framework for the media in the Republic of Uzbekistan. Article 67 of our Constitution states, "The media is free and operates in accordance with the law they are responsible for the accuracy of the information in the prescribed manner. Censorship is unacceptable" is a guarantee of absolute legal freedom of the media.

In the media, it is possible to manipulate public consciousness through a kind of semantic emphasis. Media in most cases does not describe this or that event, but convinces. This fact gives grounds to say that the language of the media, as exemplified by the German press, is ideologically loaded. In the ideologically determined language of the media, concepts are actualized, "something that defines in the form of an image some phenomena are fundamentally important for the existence of people and their communication (including speech), and this something has both universal and nationally determined significance and temporary stability". The question arises as to what linguistic means the language of the media can perform the function of speech impact.

A characteristic feature of the language of the press is a pile-up of nominative constructions with complex attributive groups, the use of these constructions is aimed at containing as much information as possible in a small text message (Vliegenthart \& Walgrave, 2011; Culpeper, 1996). There is a tendency to use incomplete sentences and a tendency to use fewer complex sentences. According to H. Elsen, here we are talking not so much about compressing information to save space and time, but rather "to create the appearance of a compressed assortment of news", in order to avoid a critical approach to the content of the presented material.

Sociologists refer to this as a mediated culture where media reflects and creates the culture. Communities and individuals are bombarded constantly with messages from a multitude of sources including TV, billboards, and magazines, to name a few. These messages promote not only products, but moods, attitudes, and a sense of what is and is not important. Mass media makes possible the concept of celebrity: without the ability of movies, magazines, and news media to reach across thousands of miles, people could not become famous. In fact, only political and business leaders, as well as the few notorious outlaws, were famous in the past. Only in recent times have actors, singers, and other social elites become celebrities or "stars."

Otakhonova, K. (2021). Cognitive principle of foregrounding in the mass-media. International Journal of Linguistics, Literature and Culture, 7(4), 194-200. https://doi.org/10.21744/ijllc.v7n4.1649 
The media outlets operate in 7 languages of the nations living in Uzbekistan and in more than 20 specialties such as political, social, economic, spiritual, education and sports. Such significant changes require further improvement of the legislative mechanism in the field, the creation of the necessary conditions for their free operation. It is noteworthy that at the regular joint session of the Oliy Majlis on November 12, 2010, the President once again focused on the information sphere in the "Concept of further deepening democratic reforms and development of civil society in the country". This Concept includes the relevant amendments and additions to the Laws "On Mass Media" and "On Principles and Guarantees of Freedom of Information' related to the field of information, as well as "On Telecommunications" and the Law on the Economic Basis of the Mass Media; It is proposed to adopt the laws "On guarantees of state support of the media", "On the transparency of public administration" and "On television and radio broadcasting".

The 3rd group of experts established under the Agency approved the Law of the Republic of Uzbekistan "On guarantees of state support of the media" and "On amendments and additions to some legislative acts in the field of mass media and access to information". The draft laws "On the introduction of pants" were prepared. These projects have been widely discussed at a number of regional and international conferences, seminars and meetings. The projects were submitted to the Cabinet of Ministers in November 2011 after approval by the relevant ministries and departments.

\section{Results and Discussions}

In the context of the transition to market relations, the editorial offices of the print media in Uzbekistan face important tasks. On the one hand, in the conditions of building a rule-of-law state and a democratic society in Uzbekistan - timely and objective informing people about the events taking place in the world, the formation of public opinion, comprehensive coverage of the reforms being implemented in the republic, which are an urgent and daily task of the press (Christen \& Gunther, 2003; Miall \& Kuiken, 1998). At the same time, it is important to preserve their national identity, centuries-old culture, traditions, educational and upbringing orientation. On the other hand, editorial offices must ensure the self-sufficiency and profitability of their publication by improving the quality and competitiveness of their products, which is the main economic condition for the freedom of the media. The manual is aimed at assisting in solving the second problem by increasing the level of knowledge of the chief editors and staff of print media about the economy and organization of the media business. The materials of the manual are intended to contribute to a more competent management of the print media as a business, their activities in a competitive environment on the basis of self-financing, the formation of economic thinking among professional journalists, an understanding of their role in strengthening the economic base of the publication and increasing its competitiveness.

The purpose and tasks facing the compilers of the book determined its nature and structure. The book is a practical guide for employees of the editorial offices of the print media. The main provisions of economic theory are revealed through the experience of specific - journalistic - editorial practice. Based on the analysis of this experience, advice and recommendations are given. The reader is introduced to various practical situations and, based on the recommendations, must solve the problems that arise in him. This contributes to the activation of the process of perception and assimilation of new knowledge, their use in editorial practice.

Today, there is no longer any doubt about the fact that the media are the main instrument of political manipulation, since they have rich and virtually unlimited possibilities of influencing the mass consciousness. It is manipulative media technologies that are one of the main and most promising ways to fight for power (Coleman, 1993; Tychkin, 2015). The content of information materials posted in the media or distributed in any other way must be objective, reliable, and must not violate the equality of candidates, electoral associations. In information television and radio programs, publications in periodicals, messages on the conduct of pre-election events, events related to the referendum should be given exclusively in a separate information block, without comments. They should not give preference to any candidate, electoral association, including the time of coverage of their election activities, the volume of printed space allocated for such messages.

Organizations producing mass media, in the event that they publish campaign and information materials (including those containing reliable information) that can damage the honor, dignity or business reputation of a candidate, the business reputation of an electoral association, must provide the relevant candidate, electoral association with the opportunity to before the end of the campaign period2 to publish (publish) a refutation or other explanation free of charge in defense of one's honor, dignity or business reputation. 
Research on the impacts of mass media began in the 1920s and 1930s, with the rise of muckraking journalismelites became concerned about the effects of investigative reporting in magazines such as McClure's on political decision-making (Hodgson et al., 2007; Cerulo, 2010). Mass media became a prominent focus of study in the 1950s after television became widely available, and academic departments dedicated to communication studies were created. These early studies investigated the cognitive, emotional, attitudinal, and behavioral effects of media on both children and adults; in the 1990s, researchers began to use those earlier studies to draw up theories concerning the use of media today in the 1970s theorists such as Marshall McLuhan and Irving J. Rein warned that media critics needed to watch how media affects people. Today, this remains a key concern; much attention has been paid, for example, to the impact on the 2016 election of false messaging distributed on social media. But the myriad forms of mass communication available today have also encouraged some researchers to begin to investigate "what people do with media".

The importance of media is enormous for politics at different levels of its activities. It stimulates citizen engagement in politics; these include political parties' membership registration, voters' registration, elections and electoral campaigns, electorates' management, are among the major political activities. Journalists perform a duty in ensuring that masses are well informed about the truth state of issues in governance. (Green-Pedersen \& Stubager, 2010; Sauppe \& Flecken, 2021) To borrow a leaf from Jakande Lateef, a veteran journalist has argued that "the Press is more important than the other functions of government for none of them has so ramifying an influence and great a power on the daily lives of millions of people". There are four major types of media, namely; traditional media, print media, electronic media and social media. Traditional media of passing information and communication is an approach based on the use of traditional devices, such as talking drums, flutes, town criers, etc. to deliver information and communicate among the people of a particular locality. The print media are approach of dissemination of information and communication through hard-wares like; newspaper, hand-bills, beam-board, pamphlet, books, magazines, journals, newsletters, novel, etc., while electronic media are methods of disseminating information and communication through electronic devices, such as television, radio, computers, microphone, megaphone, etc. from one person to another person, or from one place to another place. The media in our country today can be divided into state and non-state, as well as local media. State mass media are mass media established by the state or operating at the expense of a certain state share and funds allocated from the state budget. Local mass media - means the mass media established by local representative bodies or having their share and operating at the expense of means allocated from the local budget. Non-governmental media include media outlets established and funded by non-governmental organizations, public associations, and individuals. In democracies, the freedom of the media and the conditions under which it operates are guaranteed, but these freedoms must not be abused. First of all, the media and journalists, as mentioned above, are responsible for the accuracy of the information provided. Second, to call for forcible change of the existing constitutional order and territorial integrity of the Republic of Uzbekistan, to promote war and violence, cruelty, national, racial and religious hatred, to protect state secrets or the law Disclosure of other protected secrets, propaganda of actions that may lead to criminal liability is not allowed (Sattorova, 2020; Shen, 2007). Thirdly, insulting the honor and dignity of citizens, interfering in their private lives is also prohibited. These restrictions show once again that in a state governed by the rule of law, freedom of speech and freedom of the media are not allowed to express any opinion or point of view, but these restrictions are small and clear. The existence of a democratic state governed by the rule of law requires the restriction of a small part of the right to freedom of expression in order to preserve, albeit gradually, the progress that has been made. This is the case in developed countries, as discussed above.

\section{Conclusion}

In conclusion, in the process of forming a civil society and building a democratic state based on the rule of law in our country, it is necessary to improve the system of effective relations between public authorities and the media, which are considered the most important components of the political system. This, in turn, will be an important factor in ensuring the success of the ongoing democratic reforms. The role of the media in shaping public opinion, inculcating the ideology of national independence in the minds of our people, especially the younger generation, is invaluable. They are the most effective means of rapidly reflecting the processes of democratization and renewal of society, modernization and reform of the nation, the problems in this area.

Otakhonova, K. (2021). Cognitive principle of foregrounding in the mass-media. International Journal of Linguistics, Literature and Culture, 7(4), 194-200. https://doi.org/10.21744/ijllc.v7n4.1649 
Conflict of interest statement

The author declared that (s)he has no competing interest.

Statement of authorship

The author has a responsibility for the conception and design of the study. The author has approved the final article.

Acknowledgments

I am grateful to two anonymous reviewers for their valuable comments on the earlier version of this paper. 


\section{References}

Carroll, C. E. (2004). How the mass media influence perceptions of corporate reputation: Exploring agenda-setting effects within business news coverage (Doctoral dissertation).

Cerulo, K. A. (2010). Mining the intersections of cognitive sociology and neuroscience. Poetics, 38(2), $115-132$. https://doi.org/10.1016/j.poetic.2009.11.005

Christen, C. T., \& Gunther, A. C. (2003). The influence of mass media and other culprits on the projection of personal opinion. Communication Research, 30(4), 414-431.

Coleman, C. L. (1993). The influence of mass media and interpersonal communication on societal and personal risk judgments. Communication Research, 20(4), 611-628.

Culpeper, J. (1996). Inferring character from texts: Attribution theory and foregrounding theory. Poetics, 23(5), 335361. https://doi.org/10.1016/0304-422X(95)00005-5

Fortunato, J. A. (2006). Making media content: The influence of constituency groups on mass media. Routledge.

González-Avella, J. C., Cosenza, M. G., \& Tucci, K. (2005). Nonequilibrium transition induced by mass media in a model for social influence. Physical Review E, 72(6), 065102.

Green-Pedersen, C., \& Stubager, R. (2010). The political conditionality of mass media influence: When do parties follow mass media attention?. British Journal of Political Science, 663-677.

Gunther, A. C., Bolt, D., Borzekowski, D. L., Liebhart, J. L., \& Dillard, J. P. (2006). Presumed influence on peer norms: How mass media indirectly affect adolescent smoking. Journal of Communication, 56(1), 52-68.

Hodgson, C., Lindsay, P., \& Rubini, F. (2007). Can mass media influence emergency department visits for stroke?. Stroke, 38(7), 2115-2122.

Jones, B. D., \& Wolfe, M. (2010). Public policy and the mass media. Public policy and mass media: The interplay of mass communication and political decision making, 17-43.

Kleineberg, K. K., \& Boguná, M. (2014). Evolution of the digital society reveals balance between viral and mass media influence. Physical Review X, 4(3), 031046.

López-Guimerà, G., Levine, M. P., Sánchez-Carracedo, D., \& Fauquet, J. (2010). Influence of mass media on body image and eating disordered attitudes and behaviors in females: A review of effects and processes. Media Psychology, 13(4), 387-416.

Miall, D. S., \& Kuiken, D. (1998). The form of reading: Empirical studies of literariness. Poetics, $25(6), 327-341$. https://doi.org/10.1016/S0304-422X(98)90003-1

Mutz, D., \& Goldman, S. (2010). Mass media.

Nematovich, N. O., \& Yusupovna, K. M. (2020). THE IMPORTANCE OF MODERN METHODS AND TECHNOLOGIES IN LEARNING ENGLISH. Science and Education, 1(1).

Otten, A. L. (1992). The influence of the mass media on health policy. Health Affairs, 11(4), 111-118.

Petty, R. E., Priester, J. R., \& Brinol, P. (2002). Mass media attitude change: Implications of the elaboration likelihood model of persuasion.

Sampei, Y., \& Aoyagi-Usui, M. (2009). Mass-media coverage, its influence on public awareness of climate-change issues, and implications for Japan's national campaign to reduce greenhouse gas emissions. Global environmental change, 19(2), 203-212.

Sattorova, Z. I. (2020). ANALYSIS OF MAHMUD AL-KASHGARI SONGS IN "DIWAN LUGHAT AL-TURK". In WORLD SCIENCE: PROBLEMS AND INNOVATIONS (pp. 105-109).

Sauppe, S., \& Flecken, M. (2021). Speaking for seeing: Sentence structure guides visual event apprehension. Cognition, 206, 104516. https://doi.org/10.1016/j.cognition.2020.104516

Schmitt-Beck, R. (2003). Mass communication, personal communication and vote choice: The filter hypothesis of media influence in comparative perspective. British Journal of Political Science, 233-259.

Shen, Y. (2007). Foregrounding in poetic discourse: between deviation and cognitive constraints. Language and literature, 16(2), 169-181. https://doi.org/10.1177\%2F0963947007075983

Takeshita, T., \& Mikami, S. (1995). How did mass media influence the voters' choice in the 1993 general election in Japan? A study of agenda setting. Keio Communication Review, 17(3), 27-41.

Tychkin, P. (2015). Myth as an anthropological phenomenon in the context of modern cognitive processes. Procedia-Social and Behavioral Sciences, 166, 460-463. https://doi.org/10.1016/j.sbspro.2014.12.554

Viswanath, K., Ramanadhan, S., \& Kontos, E. Z. (2007). Mass media. In Macrosocial determinants of population health (pp. 275-294). Springer, New York, NY.

Vliegenthart, R., \& Walgrave, S. (2011). When the media matter for politics: Partisan moderators of the mass media's agenda-setting influence on parliament in Belgium. Party Politics, 17(3), 321-342.

Otakhonova, K. (2021). Cognitive principle of foregrounding in the mass-media. International Journal of Linguistics, Literature and Culture, 7(4), 194-200. https://doi.org/10.21744/ijllc.v7n4.1649 
Walther, J. B., Carr, C. T., Choi, S. S. W., DeAndrea, D. C., Kim, J., Tong, S. T., \& Van Der Heide, B. (2010). Interaction of interpersonal, peer, and media influence sources online. A networked self: Identity, community, and culture on social network sites, 17, 17-38. 